\title{
Slaughterhouse waste co-digestion - Experiences from 15 years of full-scale operation
}

\author{
A.E.W. Ek ${ }^{1}$, S. Hallin ${ }^{2}$, L. Vallin ${ }^{2}$, A. Schnürer ${ }^{3}$, M. Karlsson ${ }^{2,4}$, \\ ${ }^{1}$ Swedish Biogas International Korea Co., Ltd, Totaleco B/D 1302-7, Seocho-Dong, \\ Seocho-Gu, Seoul, Republic of Korea. \\ ${ }^{2}$ Dept. of Biogas $R \& D$, Tekniska Verken i Linköping AB, Sweden. \\ ${ }^{3}$ Dept. of Microbiology, Swedish University of Agricultural Sciences, Uppsala, Sweden. \\ ${ }^{4}$ Dept. of Physics, Chemistry and Biology, Linköping University, Linköping, Sweden \\ *Corresponding author: Tel: +46 13308419, E-mail: martin.karlsson@tekniskaverken.se, marka@ifm.liu.se
}

\begin{abstract}
At Tekniska Verken in Linköping AB (TVAB) there is a long time experience of handling and producing biogas from large volumes of slaughterhouse waste. Experiences from research and development and plant operations have lead to the implementation of several process improving technological/biological solutions. We can in this paper describe how the improvements have had several positive effects on the process, including energy savings, better odor control, higher gas quality, increased organic loading rates and higher biogas production with maintained process stability. In addition, it is described how much of the process stability in anaerobic digestion of slaughter house waste relates to the plant operation, which allow the microbiological consortia to adapt to the substrate. Since digestion of proteinaceous substrates like slaughterhouse waste lead to high ammonia loads, special requirements in ammonia tolerance are placed on the microbiota of the anaerobic digestion. Biochemical assays revealed that the main route for methane production proceed through syntrophic acetate oxidation, which require longer retention times than methane production by acetoclastic methanogens. Thus, the long retention time of the plant, accomplished by a low dilution of the substrate, is a vital component of the process stability when treating high protein substrates like slaughterhouse waste.
\end{abstract}

Keywords: Anaerobic digestion, co-digestion, full-scale, slaughterhouse waste, syntrophic acetate oxidation

\section{Introduction}

Slaughterhouse waste is the very energy-rich waste stream of meat industry [1]. As such, it is an attractive material to treat through anaerobic digestion for the production of biogas. However, there are many potential technical and microbiological problems associated with anaerobic digestion of slaughterhouse waste. These include the practical handling according to European Union Animal By-Products (ABP) Regulation [2], protein content [3] and high degradation and volatile fatty acid (VFA) formation rates [4,5]. Reported here are the experiences, production results and $\mathrm{R} \& \mathrm{D}$ activities at the full scale co-digestion biogas plant treating slaughterhouse waste in Linköping, Sweden, for the period 1997-2010.

\subsection{Anaerobic digestion of protein-rich substrate}

Anaerobic digestion of organic material is a complex microbiological process requiring the combined activity of several groups of microorganisms with different metabolic capacities which need to work in a synchronized manner in order to obtain a stable biogas process [6]. One type of key organisms are the methanogens, producing methane mainly from acetate or hydrogen and carbon dioxide. Protein-rich substrate, such as slaughterhouse waste, is a wellknown source of sulfide formation during anaerobic degradation. The increased concentration of sulfides in the digester lead to higher concentrations of corrosive $\mathrm{H}_{2} \mathrm{~S}$ in the biogas and can further lead to sulfide inhibition of the methanogens $[7,8]$. When the proteins in slaughterhouse waste are degraded, not only sulfides are formed but also ammonia [3]. The released ammonia increases the $\mathrm{pH}$ in the digester and with a large ratio of slaughterhouse waste in the substrate mixture, the $\mathrm{pH}$ tends to reach over 8.0, which can be growth limiting for some VFA consuming methanogens [9]. The above optimal $\mathrm{pH}$, together with a high 
fermentation rate of proteins and fats in the slaughterhouse waste can lead to an accumulation of fatty acids. Thus, if the organic load to the digester is not decreased at that point, the process overload can lead to increasing concentrations of process inhibiting fatty acids, the consequential $\mathrm{pH}$ drop and finally to a total inhibition of methanogenesis and process collapse will follow. The released ammonia $\left(\mathrm{NH}_{3}\right)$ from protein degradation is in equilibrium with the less harmful ionized ammonium species $\left(\mathrm{NH}_{4}{ }^{+}\right)$. However, the non-ionized form is itself also a source of inhibition of microorganisms, since the neutral $\mathrm{NH}_{3}$ can easily pass through cell membranes of bacteria and archaea and upon entering the cell disrupt e.g. intra-cellular $\mathrm{pH}$ and concentrations of other ions [8]. Thus, methods to lower ammonia levels in anaerobic digesters treating high-protein substrates are desirable and subject to active research [10,11]. Furthermore, at increased $\mathrm{pH}$ and temperature, the equilibrium is shifted towards the toxic ammonia, resulting in a positive correlation between toxicity effects and increasing $\mathrm{pH}$ and temperature [12]. Among the methanogens, the acetate-utilizing methanogens have been suggested to be responsible for $70-80 \%$ of the methane produced [6]. However, recent results suggest that an alternative methane producing pathway is activated at elevated levels of ammonia [13]. In this pathway, acetate is converted to hydrogen and carbon dioxide by syntrophic acetate oxidizers (SAO), followed by the subsequent reduction of carbon dioxide to methane by hydrogen utilizing methanogens, i.e. by this pathway methane is produced by hydrogenotrophic methanogens only. Development of SAO has been shown to occur due to a selective inhibition of acetate-utilizing methanogens by ammonia, released e.g. during the degradation of proteins [13].

\subsection{Co-digestion plant design and operation}

The plant for co-digestion of slaughterhouse waste started operation in 1996. The plant is operated by the company Svensk Biogas AB (SvB), a subsidiary to TVAB, and has since start-up continuously supplied upgraded vehicle-fuel quality biomethane. TVAB has an inhouse Biogas R \& D department, which continuously work to support production and improve plant performance. Biogas process research is further conducted in collaboration with Linköping University and the Swedish University of Agricultural Sciences [14,15].

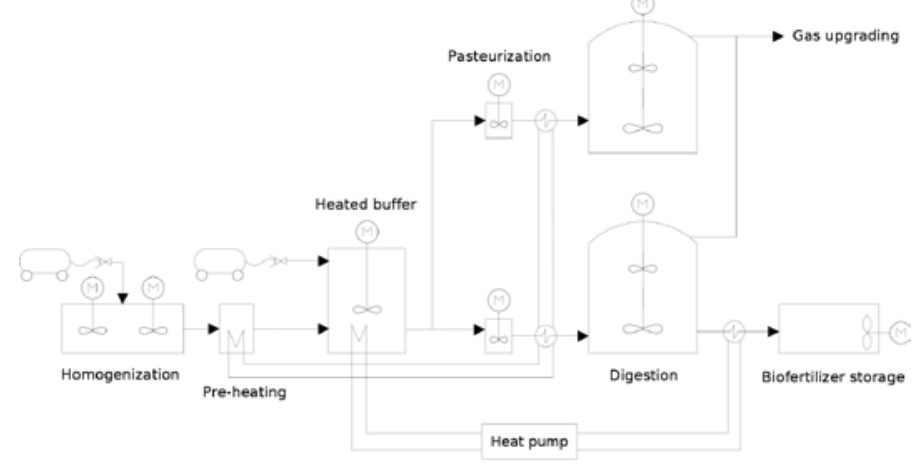

Figure 1. Schematic diagram of the process at Linköping Biogas plant.

The co-digestion plant consists of three basic parts: 1) substrate reception and storage, 2) pasteurization equipment, and 3) anaerobic digesters (Fig. 1). Yearly capacity of the plant is 55000 metric tons, and the proportion of slaughterhouse waste in the total substrate mixture has varied between 35 and $75 \%$ (w/w, yearly average). During 2010, the capacity of the plant was expanded to 100000 tons/year.

Slaughter house waste is treated with formic acid at the slaughter house and all waste is delivered to the plant by closed trucks in a grinded $(\leq 12 \mathrm{~mm})$ pumpable form and is either 
transferred into a combined homogenization and buffer tank or directly into a second, heated buffer tank. After homogenization the substrate mixture is continually pumped to the second heated buffer tank. The target temperature of the second buffer tank is above $75^{\circ} \mathrm{C}$ to avoid foaming, to pre-heat the material before pasteurization and to provide a stable thermal disintegration of the substrate. Substrate which is delivered warm is pumped directly to the heated buffer tank to save energy on substrate heating. Before loading of the digesters, the substrate is pasteurized in a batch process for one hour at $70^{\circ} \mathrm{C}$, to fully comply with the EU $\mathrm{ABP}$ regulation for category three materials [2]. The anaerobic digestion takes place at mesophilic conditions $\left(38^{\circ} \mathrm{C}\right)$ and the process heat is supplied through the city's waterborne district heating system. The two digesters are continuously stirred tank reactors (CSTR) run in parallel, with a total volume of $7400 \mathrm{~m}^{3}$ and a hydraulic retention time (HRT) of 45-55 days. The gas composition is, on average, $68 \% \mathrm{CH}_{4}, 31 \% \mathrm{CO}_{2}$ and $<100 \mathrm{ppm} \mathrm{H}_{2} \mathrm{~S}$. No significant modification to the plant has been necessary, as a consequence of $\mathrm{ABP}$ regulation implementation, since the plant was already equipped with the required pasteurization function. However, the precise categorization of different substrates of animal origin has changed over the years, as legislation and its interpretation have changed.

\section{Materials and methods}

\subsection{Operation and analysis data}

Operational data on bi ogas production, biogas composition and the amount and type of incoming substrates were collected from the plant's SCADA-system. $\mathrm{pH}$ was analyzed with a WTW $526 \mathrm{pH}$ meter (WTW Inolab, USA), according to Swedish Standard SS 028122:2. Partial (bicarbonate) alkalinity was analyzed by titration to $\mathrm{pH} 5.4, \mathrm{w}$ ith simultaneous removal of $\mathrm{CO}_{2}$, in accordance with Swedish standard SS-EN ISO 9963 Part 2.

Total solids (TS) and volatile solids (VS) were analyzed according to Swedish Standard SS 028113. VFAs were analyzed with a modified spectroscopic HACH method (HACH no. 8196). Dissolved free ammonium nitrogen was analyzed according to FOSS Tecator's Kjeltec method, on a Kjeltec 2200 (Foss Tecator, Denmark). The method gives the concentration of total dissolved free ammonium including a minor fraction of dissolved ammonia nitrogen. $\left(\mathrm{NH}_{4}{ }^{+}-\mathrm{N}(\mathrm{aq})+\mathrm{NH}_{3}-\mathrm{N}(\mathrm{aq})\right)$.

\subsection{Labeling experiments}

Inoculation of digester samples with isotopically labeled acetate was performed in order to distinguish between methane formation by acetate utilizing methanogens or via syntrophic acetate oxidation and hydrogenotrophic methanogens. Aliquots of digester content $(20 \mathrm{ml})$ were transferred during flushing with $\mathrm{N}_{2} / \mathrm{CO}_{2}(80 / 20$ percent $)$ to sterile serum vials $(118 \mathrm{ml})$. The bottles were closed with butyl rubber stoppers and aluminum caps and the labeling studies were started by the addition of $\left(2{ }^{14} \mathrm{C}\right.$ )-acetate (Amersham, England) to a $\mathrm{f}$ inal concentration of $10 \mathrm{kBq} / \mathrm{ml}$. The culture was incubated at $37{ }^{\circ} \mathrm{C}$ and the degradation of (2${ }^{14} \mathrm{C}$ )-acetate and the concomitant formation of ${ }^{14} \mathrm{CH}_{4}$ and ${ }^{14} \mathrm{CO}_{2}$ were determined by scintillation counting. The labeling pattern was analyzed when approximately $90 \%$ of the labeled acetate had been converted. Finally, the ratio of ${ }^{14} \mathrm{CO}_{2} /{ }^{14} \mathrm{CH}_{4}$ was determined and values above 1 were considered as evidence for SAO.

\section{Results}

\subsection{Operational strategy development}

During the two first years of operation about $50 \%(\mathrm{w} / \mathrm{w})$ of the substrate consisted of cattle manure. This is a common way to avoid problems with process overloading, 
nitrogen/ammonia inhibition and micronutrient deficiency [16,17]. However, diluting the substrate mixture with manure has the negative effect of decreasing the amount of methane produced per reactor volume, since the methane yield of manure is far lower than that of slaughterhouse waste [18]. To increase the profitability of the plant, and to meet the increased demand for biomethane as a vehicle fuel, a gradual replacement of manure with more slaughterhouse and other organic wastes with higher methane potential have been implemented (fig. 2B).

\subsubsection{Organic load of digesters and biogas production}

At start-up, the plant was designed for a substrate mixture with a TS maximum of $8 \%$. However, as a result of the constant endeavor to increase the organic load and thereby methane production, the TS of the incoming substrate mixture, sampled in the heated buffer tank, has during 2009/2010 reached a TS of $17 \%$ as a yearly average (Fig. 2A), with individual samples during 2009/2010 sometimes reaching $20 \%$. A replacement of steam injection with district heating for pasteurization in 2007, also led to a thicker substrate mixture, since added water no longer enter the system through the steam.
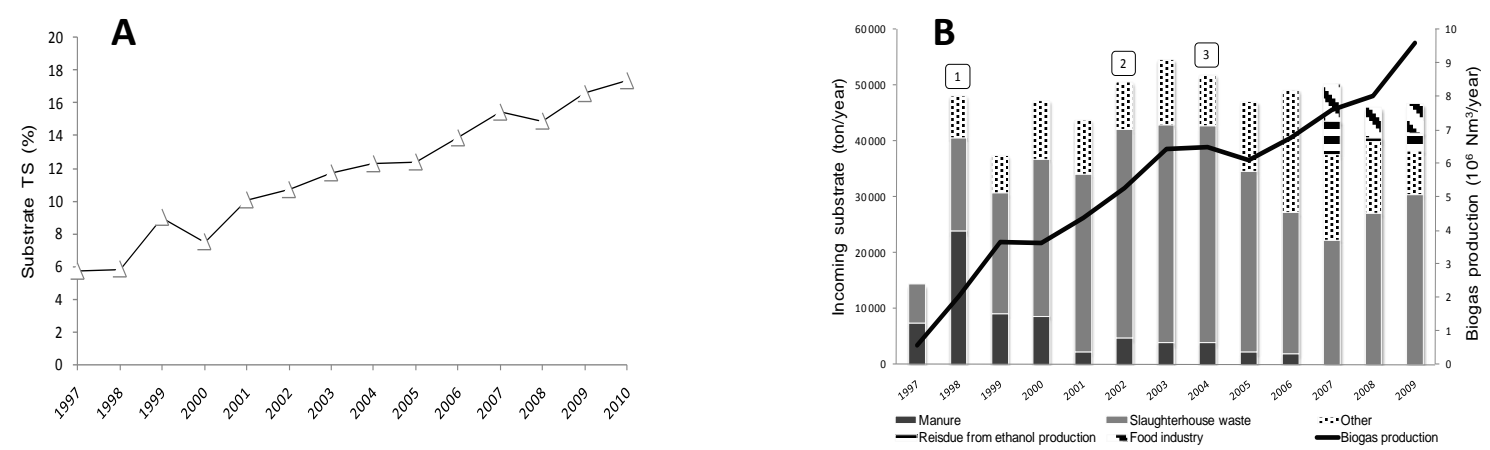

Figure 2. A) Total solids (TS) of incoming substrate (yearly average) during 1997-2010 (data for 2010 up until 2010-05-06), sampled in the heated buffer tank. B) Annual amount of substrate, substrate composition and biogas production during 1997 - 2009. Number captions denote implementation of process additives: [1] $\mathrm{FeCl}_{2}$; [2] hydrochloric acid; [3] $\mathrm{KMB1}$.

As can be seen in Fig. 2B, the plant has experienced an almost unbroken increase of yearly biogas production. In 2009 the average volumetric biogas production reached an average of $3.6 \mathrm{Nm}^{3} /\left(\mathrm{m}^{3}{ }_{-} \mathrm{R} \cdot \mathrm{d}\right)$ and a yearly total production of 9.6 million $\mathrm{Nm}^{3}$.

\subsection{Main achievements in process stabilization and optimization}

The cut down in manure usage put a focus on process development, which was facilitated by three main appendages to the operational strategy of the plant; 1) addition of ferrous chloride, 2) addition of hydrochloric acid and 3) addition of the process additive KMB1 (Fig. 2B).

\subsubsection{Addition of ferrous chloride}

Sulfide-associated problems, such as corrosive $\mathrm{H}_{2} \mathrm{~S}$ in the biogas and sulfide-inhibition of the methanogenesis are both reduced by precipitation of sulfides with $\mathrm{Fe}(\mathrm{II})$. At the plant, the addition of ferrous chloride to the homogenization and pasteurization tanks commenced in May 1998 and as a result, the sulfide concentration in the digesters and the concentration of $\mathrm{H}_{2} \mathrm{~S}$ in the biogas were reduced, as well as the sulfur load on the water scrubbers [19]. The use of ferrous chloride has continued since 1998 and because the addition of the precipitant is made already in the homogenization and pasteurization tanks, the $\mathrm{H}_{2} \mathrm{~S}$-induced odors from the buffer and pasteurization tanks are also reduced. 


\subsubsection{Addition of hydrochloric acid}

Laboratory tests, with addition of hydrochloric acid to co-digestion reactors operated under mesophilic conditions were performed in 1999-2000 [20]. Positive effects on volumetric gas production and VFA levels were noted in the digesters where $\mathrm{pH}$ was lowered with hydrochloric acid and full-scale acid addition was started at the plant in March 2002. On comparison of the operation performance of the plant in 2000-2001 with 2002-2003, the following direct and indirect effects were observed [19]: digester loading rate could be increased with $70 \%$ on VS basis, gas production increased, acetate concentration decreased by $43 \%$ and partial alkalinity concentration increased from $11000 \mathrm{mg} / \mathrm{L}$ to $17000 \mathrm{mg} / \mathrm{L}$. On average, between the two periods, the amount of material increased by $20 \%$ (fig 2B) whereas the dry substance of the material increased with $26 \%$ during the same period (fig. $2 \mathrm{~A}$ ). Since also the percentage of slaughter house waste increased from 59 to $72 \%$ in the material, the VS percentage of TS increased. Thus, the gas production increase was a result of the increased loading rate since the specific methane yield per $\mathrm{kg}$ VS was unchanged.

\subsubsection{Addition of process additive KMB1}

To further enhance process stability, and to increase the efficiency of the plant, a process additive known as KMB1 was developed at TVAB [21]. The main effects of the additive were: (1) more stable production, enabling (2) higher organic loading rate without process disturbances and heavy foaming [19], leading to (3) higher methane production. Also, the additive enabled the decrease and final removal of manure in the substrate mixture, and has been added to the plant since November 2003.

\subsection{Plant performance after process improvements}

After implementation of the three process improving additives mentioned above, a closer study of the process reveal the positive effects (data from 2004-2005). In the heated buffer tank the VFA levels fluctuate to a g reat extent and can occasionally get very high (up to $16000 \mathrm{mg} / \mathrm{L}$ ) while the $\mathrm{pH}$ is low (Fig. 3A). However, even though the buffer tank substrate display a low $\mathrm{pH}$ and high, fluctuating VFA concentrations (average $8400 \mathrm{mg} / \mathrm{L}, \mathrm{pH} 5.5$ ), the concentration of VFA in the digester is low and stable (average $1600 \mathrm{mg} / \mathrm{L}, \max 2800 \mathrm{mg} / \mathrm{L}$ ) and the digester fluid has a stable $\mathrm{pH}$ of 8.0 (7.9-8.1).
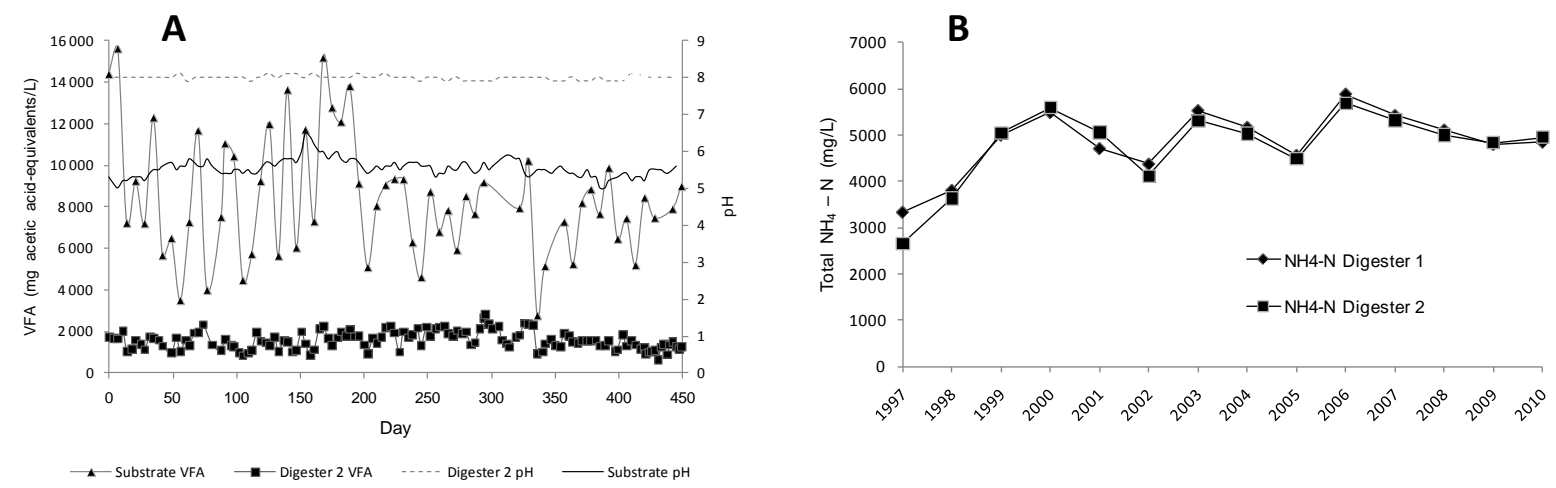

Figure 3 A). Volatile fatty acid (VFA) concentrations (mg acetic acid-equivalents/L) and pH levels in the heated buffer tank (denoted: substrate) and in the biogas digester (data from 2004-2005). B) Total ammonium $\left(\mathrm{NH}_{4}{ }^{+}-\mathrm{N}(\mathrm{aq})+\mathrm{NH}_{3}-\mathrm{N}(\mathrm{aq})\right)$ concentrations $(\mathrm{mg} / \mathrm{L})$ in the digesters during 1997-2010.

Since the plant's early years of operation, the total $\mathrm{NH}_{4}-\mathrm{N}$ concentration has been high. The average for both digesters during 1999-2010 has been $5060 \mathrm{mg} / \mathrm{L}$, with a maximum yearly 
average of $5880 \mathrm{mg} / \mathrm{L}$ (digester 1, 2006) and a minimum yearly average of 4120 (digester 2 , 2002) (Fig. 3B). Labeling experiments were performed in 2008 to establish what type of methane formation pathway is prevalent - methane formation by acetate utilizing methanogens or via syntrophic acetate oxidation and hydrogenotrophic methanogens?

The labeling analysis showed production of high levels of labeled carbon dioxide in relation to labeled methane. The ${ }^{14} \mathrm{CO}_{2} /{ }^{14} \mathrm{CH}_{4}$ quota was determined to be 16 ; clearly showing that methane production in the digester occurred mainly through syntrophic acetate oxidation and hydrogenotrophic methanogenesis. Since the digester is operated at high ammonium levels (5300 $\mathrm{mg} \mathrm{NH}{ }_{4}{ }^{-}-\mathrm{N} / \mathrm{L}$ at the time of sampling) this is a result that was expected and in accordance with the previous studies that have shown development of SAO in response to increasing ammonia levels ${ }^{13}$. The development of this prevailing metabolic pathway is likely the explanation to the stable operation of the process even at high ammonia levels. Given that methanogenesis via syntrophic acetate oxidation involves a hydrogenotrophic methanogen, that tolerates higher levels of ammonia than acetoclastic methanogens, methane production from acetate can still proceed even though the acetoclastic methanogens are inhibited. Furthermore, isolation and characterization of several ammonia tolerant hydrogen utilizing methanogens, as well as ammonia tolerant syntrophic acetate oxidizing bacteria, support this suggested mechanism for ammonia adaptation in biogas processes [22-24]. However, the generation time of a S AO culture was calculated to be approx. 28 days [13] which can be compared with the times of around 2 - 12 day for acetate utilizing methanogens [25]. Thus, the long retention time would seem to be a prerequisite to allow SAO to establish in the digester.

\subsection{Practical experiences}

The general plant operation experiences of anaerobic digestion of slaughterhouse waste concern two main themes: 1) logistics and transportation and 2) process and technology. At the slaughterhouse, the waste is grinded to $\leq 12 \mathrm{~mm}$ and treated with formic acid. The grinding at the slaughterhouse allows for transportation of the substrate in slurry form, and thereby a closed-system handling at the biogas plant, which prevents odor problems. Treatment with formic acid prevents foaming which would otherwise cause significant problems during transport and storage at the biogas plant. The thermal disintegration of the substrate in the heated buffer tank, and the fact that the substrate temperature is over $70{ }^{\circ} \mathrm{C}$ in large parts of the system, reduces potential problems with clogging and eases pumping of the substrate due to reduced viscosity. Furthermore, to achieve a stable process the type of material co-digested with the slaughterhouse waste is important, and the complimentary substrates should work well in the plant, both from a practical and a process point of view, which will lead to an even substrate mixture over time and thus an even organic loading rate and a stable biogas process.

\section{Conclusions}

From the long time experiences the following conclusions are established:

- It is possible to operate CSTR co-digestion of slaughterhouse waste, at substrate TS levels significantly over the original design level.

- The plant is operating well at high levels of ammonium, and the long HRT (4555 day) enables establishment of a mesophilic syntrophic acetate oxidizing culture.

- With optimization of process parameters, substrate composition and through the addition of process additives, it has for 15 years been possible to achieve a continued increase of the biogas production, with basically the original plant capacity. 


\section{References}

[1] Edström M., Nordberg Å., Thyselius L. Anaerobic treatment of animal byproducts from slaughterhouses at laboratory and pilot scale. Applied Biochemistry and Biotechnology, 109 (13), 2003, pp. 127 - 138.

[2] European Community. Regulation (EC) No. 1774/2002 of the European Parliament and of the Council laying down health rules concerning animal by-products not intended for human consumption. Official Journal, L 273, 2002, pp. 1 - 95.

[3] Hejnfelt A. and Angelidaki, I. Anaerobic digestion of slaughterhouse by-products. Biomass and Bioenergy 33 (8), 2009, pp. 1046 - 1054.

[4] Salminen E., Einola J., Rintala J. Characterisation and anaerobic batch degradation of materials accumulating in anaerobic digesters treating poultry slaughterhouse waste. Environ. Technol. 22 (5), 2001, pp. 577 - 585.

[5] Salminen E. and Rintala J. Semi-continuous anaerobic digestion of solid poultry slaughterhouse waste: effect of hydraulic retention time and loading. Water Research 36 (13), 2002, pp. 3175 - 3182.

[6] Zinder S. H. Microbiology of Anaerobic Conversion of Organic Wastes to Methane: Recent Developments. ASM news, 50 (7), 1984.

[7] Ochieng' Otieno F. A. Anaerobic digestion of wastewaters with high strength sulphates. Discovery and Innovation 8 (2), 1996, pp. 143 - 150.

[8] Chen Y., Cheng J. J., Creamer K. S. Inhibition of anaerobic digestion process: A review. Bioresource Technology 99 (10), 2008, pp. 4044 - 4064.

[9] Jiunn-Jyi L., Yu-You L., Noike, T. Influences of pH and moisture content on the methane production in high-solids sludge digestion. Water Research 31 (6), 1997, pp. 1518 - 1524.

[10] Tada C., Yang Y., Hanaoka T., Sonoda A., Ooi K., Sawayama S. Effect of natural zeolite on methane production for anaerobic digestion of ammonium rich organic sludge. Bioresource Technology 96 (4), 2005, pp. 459 - 464.

[11]Nordell E., Hallin S., Johansson M., Karlsson M. The diverse response on degradation rate of different substrates upon addition of zeolites. Third International Symposium on Energy from Biomass and Waste, Venice, Italy, 2010. ISBN 978-88-6265 -008-3.

[12] Siegrist H., Vogt D., Garcia-Heras J.L., Gujer W. Mathematical model for meso- and thermophilic anaerobic sewage sludge digestion. Environmental Science and Technology, 36 (5), 2002, pp. 1113 - 1123.

[13] Schnürer A. and Nordberg A. Ammonia, a selective agent for methane production by syntrophic acetate oxidation at mesophilic temperature. Water Science and Technology 57 (5), 2008, pp. 735 - 740.

[14]Hellman J., Ek A. E. W., Sundberg C., Johansson M, Svensson B. H. and Karlsson M. Mechanisms of increased methane production through re-circulation of magnetic biomass carriers in an experimental continuously stirred tank reactor. $12^{\text {th }}$ World Congress on anaerobic digestion, Guadalajara, Mexico, 2010.

[15]URL: http://microdrive.phosdev.se/index.php?page=Companies

[16] Tafdrup S. Centralized biogas plants combine agricultural and environmental benefits with energy production. Water Science and Technology 30 (12), 1994, pp. 133 - 141. 
[17]Alvarez R. and Lidén G. Semi-continuous co-digestion of solid slaughterhouse waste, manure, and fruit and vegetable waste. Renewable Energy 33 (4), 2008, pp. 726 - 734.

[18]Deublein D. and Steinhauser A. Biogas from waste and renewable sources. Weinheim, Germany. Wiley-VCH, 2008.

[19] Vallin L, Christiansson A., Arnell M., Undén P. D2.2 Operational experiences of cost effective production in Linköping, Sweden. Biogasmax Integrated Project No. 019795, 2007.

[20]Ejlertsson J. (2005). Swedish Patent No SE 525313.

[21] Holm S., Ejlertsson J., Carlson B. (2005). Swedish Patent No SE 526875.

[22] Schnürer A., Schink B., Svensson B.H. Clostridium ultunense sp. nov., a mesophilic bacterium oxidizing acetate in syntrophic relationship with a hydrogenotrophic methanogenic bacterium. International Journal of Systematic Bacteriology 46 (4), 1996, pp. $1145-1152$.

[23] Schnürer A., Zellner G., Svensson B.H. Mesophilic syntrophic acetate oxidation during methane formation in different biogas reactors. FEMS Microbiology Ecology 29, 1999, pp. $249-261$

[24]Karlsson M., Roos S., Schnürer A. Description of 'Candidatus Syntrophicus schinkii' an anaerobic, syntrophic acetate-oxidizing bacterium isolated from mesophilic digester operating at high concentration of ammonia. FEMS Microbiology Letters, 309 (1), 2010, pp. $100-104$.

[25]Jetten M. S. M., Stams A. J. M., Zehnder A. J. B. Methanogenesis from acetate: A comparison of the acetate metabolism in Methanothrix soehngenii and Methanosarcina spp. FEMS Microbiology Letters, 88 (3-4), 1992, pp. 181 - 197. 